\title{
Two Different Types of Atypical Kounis Syndrome in the Same Patient at Different Times: A Case Report
}

İlginç Bir Olgu: Farklı Zamanlarda Iki Farklı Tipiyle Atipik Kounis Sendromu

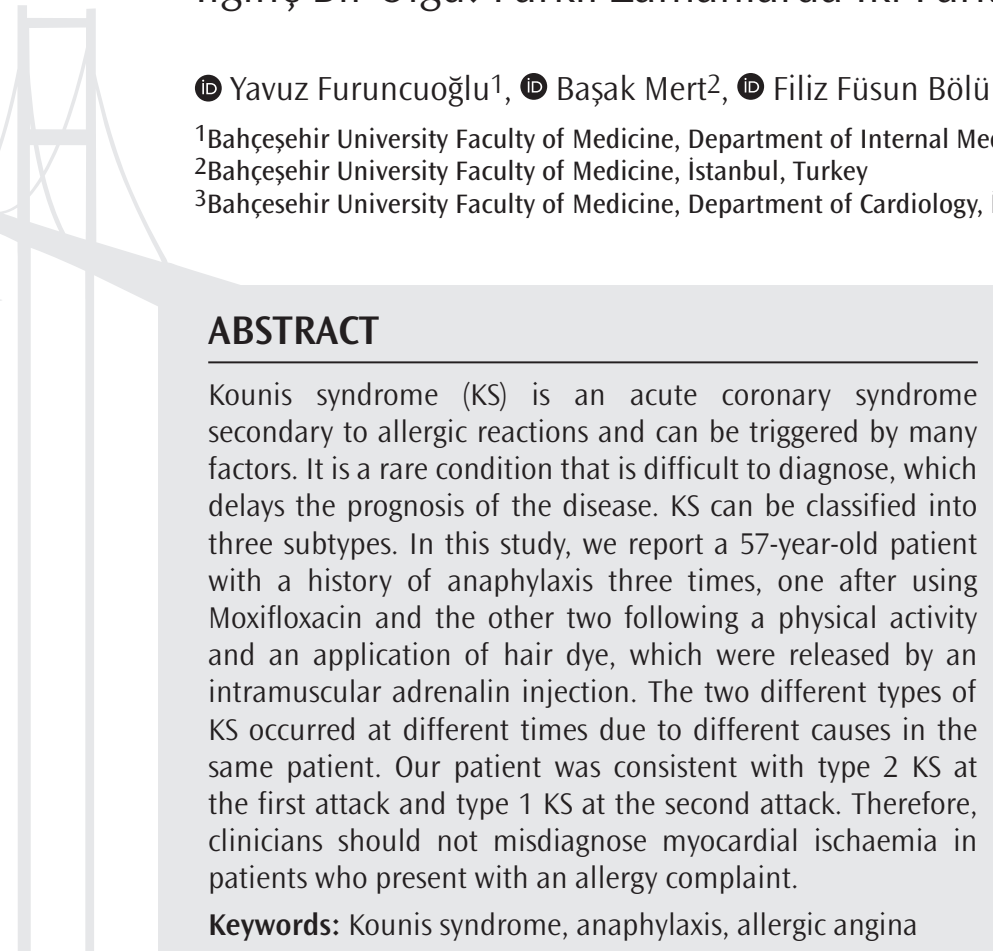

\section{öz}

Kounis sendromu (KS) ilaçlar, çevresel etkenler ve diğer birçok durumla tetiklenebilen alerjik reaksiyonlara seconder gelişen akut koroner sendromdur. KS nadir görülmesi sebebiyle tanı konulması güç bir durumdur. Erken tanı ve tedavi ise prognoz için önem arz etmektedir. Bu olgu sunumunda 57 yaşındaki hastanın biri Moksifloksasin kullanımı sonrası, bir diğeri fiziksel aktivite sonrası olmak üzere üç anafilaksi öyküsü bulunmaktadır. Kısaca, hastada farklı zamanlarda, farkı sebeplerle gelişen iki farklı Kounis tipi mevcuttur. İlk atakta ve devamlı görülen tip 2 KS'ye, ikinci atakta tip 1 KS eklenmiştir. Klinisyenler gögüus ağrısı, yükselmiş kardiyak enzimler, elektrokardiyografi ve ekokardiyografi değișikliklerine eşlik eden alerjik reaksiyon bulgularında alerjik miyokard enfarktüsünü de akıllarına getirmeliler.

Anahtar Kelimeler: Kounis sendromu, anafilaksi, alerjik anjina

\section{Introduction}

Kounis syndrome (KS) was defined by Kounis and Zavras (1) in 1991 as a chest pain in the course of an anaphylactic reaction related to mast cell activation. It may be seen as angina pectoris or myocardial infarction (MI) with normal coronary arteries $(1,2)$. The $\mathrm{KS}$ can be classified into three subtypes: type 1 patients suffer from chest pain associated with an acute allergic reaction and have no predisposing factors for coronary heart disease (3); type 2 presents in patient with primary coronary artery disease (CAD) and may cause plaque erosion or rupture $(2,3)$ and type 3 patients suffer stent thrombosis (4). The various clinical manifestations of KS are chest pain, nausea, vomiting, syncope, pruritus, urticaria, palpitations and almost half of the patients suffer from respiratory manifestations including wheezing, stridor, rhinitis and dyspnoea (5). KS may be initiated by drugs, foreign bodies, diseases caused as a result of release of chemical mediators such as histamine, leukotrienes, chemokines and cytokines $(6,7)$. Immunoglobulin E (IgE) and tryptase may be elevated in KS. An early diagnosis of KS is important for the prognosis and treatment of it.

\section{Case Report}

A 57-year-old woman presented with chest pain, palpitations, sweating, cough, weakness and near syncope. She had taken amoxicillin for pneumonia. She had a previous history of allergy but not of any CAD. Her history also included anaphylaxis three times, one after using Moxifloxacin and the other two following a physical activity and an application of hair dye, which were released by intramuscular adrenalin injection. Furthermore, she was allergic to Moxifloxacin, diazepam, iodine, Benzydamine oral spray, cinnamon, pistachio and peanut. Her medication included levothyroxine for the treatment of Hashimoto's thyroiditis. She was a tobacco smoker for 25 pack-years. She had a family history of Parkinson's disease, diabetes mellitus, bladder and colon cancer. Her vital signs were stable when she presented to the emergency 
room. She was presented with acute-onset chest pain, accompanied by allergic symptoms. Cardiac enzymes (Troponin, creatine kinaseMB) were normal. Antinuclear antibodies, anti-dsDNA, complete blood count, brain natriuretic peptide urea/creatinine, aspartate aminotransferase/alanine aminotransferase, lactate dehydrogenase/ creatine phosphokinase, tryptase, antithrombin III, thyroid stimulating hormone, C3, C4 and D-dimer were normal. The abnormal test results were LDL: $157 \mathrm{mg} / \mathrm{dL}$ and IgE: 384 ( $\mathrm{n}<100)$. Anthelmintic treatment was administered to eradicate any other possible cause of IgE elevation. Hepatitis B virus and hepatitis C virus serology were also negative. Abdominal ultrasonography and computerized tomography (CT) were normal. Thorax CT was performed showing bronchiectasis in small region.

Electrocardiography (ECG): Normal (Figure 1), echocardiography showed segmental left ventricular motion abnormality, but ejection fraction was normal, coronary angiography also revealed right coronary artery (RCA) spasm in the midportion and plaques in the left anterior descending (35\%-50\%) and circumflex arteries (Figures 2, 3). The RCA diameter was expanded after intravenous nitrate injection. Diltiazem, clopidogrel, statin, isosorbide mononitrate and, if necessary, isosorbide dinitrate were started as a maintenance therapy. After 15 months, the patient was readmitted with anaphylaxis-associated chest pain, amaurosis fugax and filiform pulse while dyeing her hair. She had taken nitroglycerine spray and acetylsalicylic acid when chest pain began prior to being admitted. Cardiac enzymes and transthoracic echocardiography were normal, ejection fraction was calculated as 55\%. ECG: Normal (Figure 4), IgE: 322. Coronary angiography was performed showing no abnormal pathology. At that time, it was thought that the patient might have KS.

Parenteral $\mathrm{H} 1$ blocker and steroid were added to the treatment. No additional complaint was reported by the patient after being followedup for three days. Drugs were adjusted and the patient was referred to the allergy department for allergic MI.

The patient gave a verbal and written consent before participating in the study.

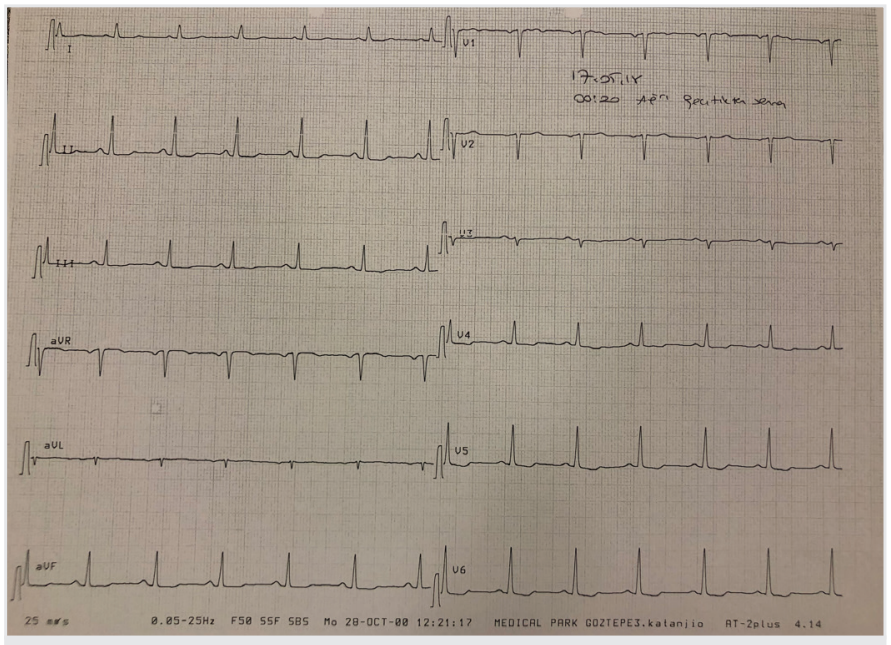

Figure 1. Normal electrocardiography of the patient when she was first admitted to the emergency service

\section{Discussion}

We present an interesting case of $\mathrm{KS}$ in a patient with an uncommon clinical presentation, which is significant for the awareness of KS. First, despite the recurrent anaphylaxis, there were no abnormalities in ECG and cardiac enzymes. Second, while using anti-ischaemic and antilipemic therapies, Kounis attacks reoccurred due to the allergic reactions

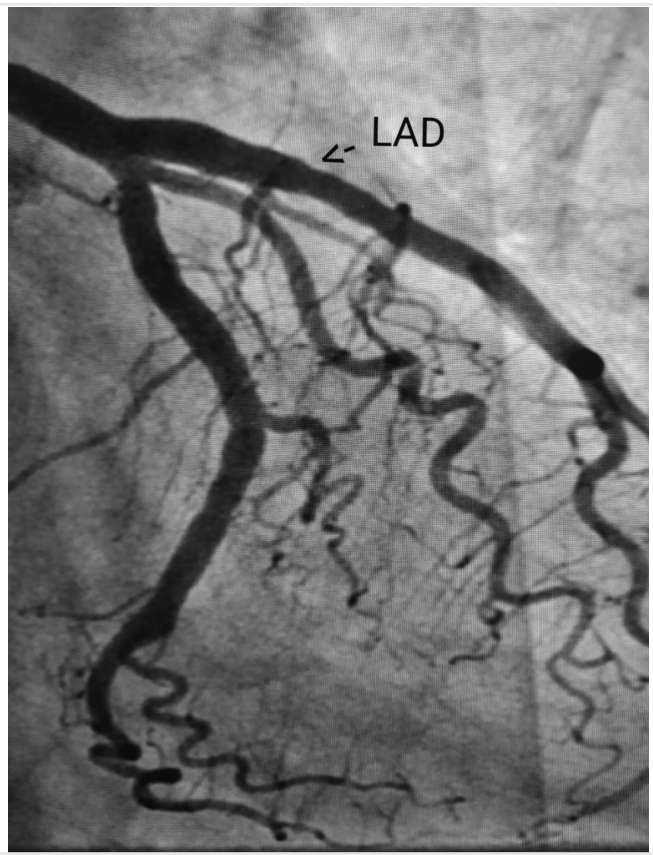

Figure 2. Coronary angiography shows non-critical plaques in the LAD (35\%-50\%) and $\mathrm{Cx}$

LAD: left anterior descending

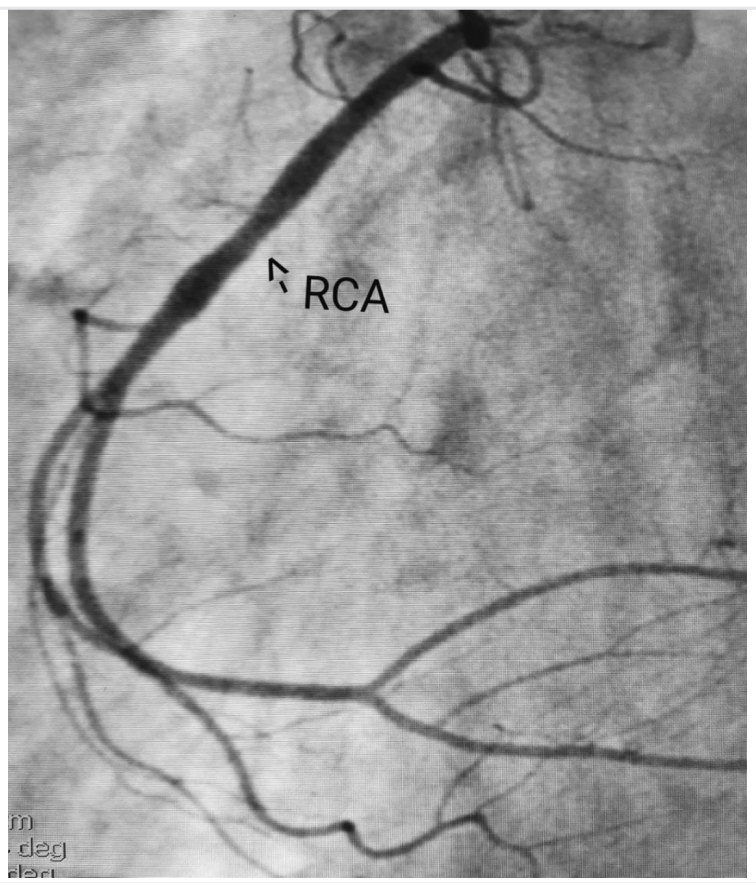

Figure 3. Coronary angiography revealed right coronary artery spasm in the midportion

RCA: right coronary artery 


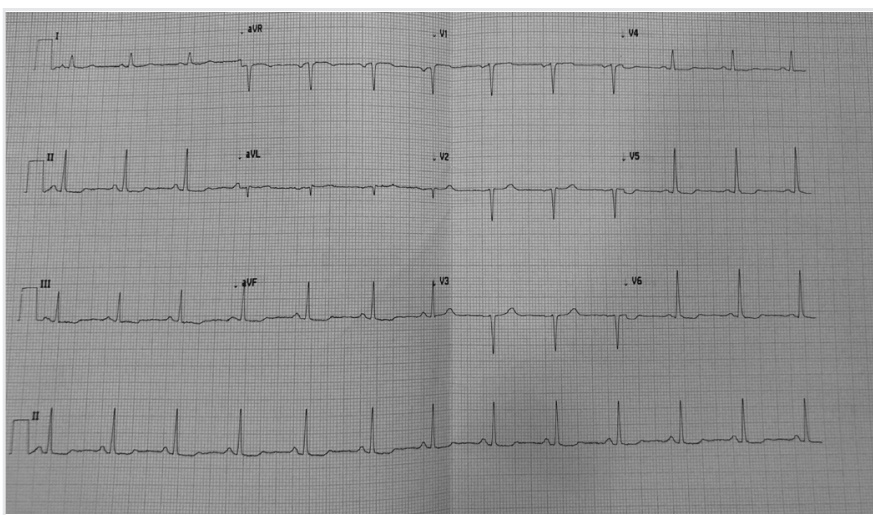

Figure 4. Normal electrocardiography of the patient after 15-months when she was readmitted to the hospital

even when narrowing disappeared. Briefly, the patient experienced two different types of KS at different times due to different causes - the consistent type $2 \mathrm{KS}$ at the first attack and type $1 \mathrm{KS}$ at the second.

The plaques were seen in the coronary arteries at the first coronary angiography, normal troponin but abnormal echo findings were observed, and the patient had used an antibiotic that had caused the KS. The second coronary angiography was normal when the patient had used a hair dye.

KS refers to varying degrees from myocardial ischaemia to infarction as a result of allergic and anaphylactic reactions. It could be presented as a broad clinical spectrum differing from only chest pain to ST segment elevated MI. Allergic reactions may be subclinical, acute or chronic. KS may develop for many reasons; antibiotics and other drugs (8).

Nitrates, calcium blockers, anti-histaminic and steroids are used to treat type $1 \mathrm{KS}$, whereas antithrombotic drugs are required for type 2 KS (9). Clinicians should not misdiagnose myocardial ischaemia in patients who present with an allergy complaint.

In our case, there were changes in echocardiogram (ECHO) and clinical findings considering ischaemic heart disease, however, no change in enzymes or ECG were seen. Coronary angiography was performed. Ischaemic coronary arteries and vasospasm were seen. Fifteen months later, second coronary angiography was performed due to the chest pain and anaphylaxis, but the coronary arteries were normal.

\section{Conclusion}

To conclude, we suggest that clinicians should always consider KS as a differential diagnosis if there are any signs and symptoms of allergy and ischaemic heart disease such as changes in ECG, ECHO or enzymes.

\section{Ethics}

Informed Consent: Verbal and Written informed consent was obtained from the patient.

Peer-review: Internally peer-reviewed.

Authorship Contributions: Surgical and Medical Practices- Y.F., T.G. ; Concept- Y.F., B.M., F.F.B., C.B. ; Design- Y.F., B.M., C.B ; Data Collection or Processing- Y.F., B.M., T.G., C.B ; Analysis or Interpretation- Y.F., F.F.B., T.G. ; Literature Search- Y.F., B.M. ; Writing- Y.F., B.M., F.F.B.

Conflict of Interest: No conflict of interest was declared by the authors.

Financial Disclosure: The authors declared that this study received no financial support.

\section{References}

1. Kounis NG, Zavras GM. Allergic angina and allergic myocardial infarction. Circulation 1996; 94: 1789.

2. Kounis NG. Kounis syndrome (allergic angina and allergic myocardial infarction): a natural paradigm? Int J Cardiol 2006; 110: 7-14.

3. Kounis GN, Soufras GD, Kouni SA, Kounis NG. Hypersensitivity myocarditis and hypersensitivity coronary syndrome (Kounis syndrome). Am J Emerg Med 2009; 27: 506-8.

4. Akyel A, Murat SN, Cay S, Kurtul A, Ocek AH, Cankurt T. Late drug eluting stent thrombosis due to acemetacine: type III Kounis syndrome: Kounis syndrome due to acemetacine. Int J Cardiol 2012; 155: 461-2.

5. Kogias JS, Sideris SK, Anifadis SK. Kounis syndrome associated with hypersensitivity to hymenoptera stings. Int J Cardiol 2007; 114: 252-5.

6. Mazarakis A, Goudevenos J, Kounis NG. Coronary vasospasm induced by cytostatic drugs: Kounis syndrome seems to be the most likely culprit. Hellenic J Cardiol 2013; 54: 482-5

7. Kounis NG. Kounis syndrome (allergic angina and allergic myocardial infarction): a natural paradigm? Int J Cardiol 2006; 110: 7-14.

8. Mazarakis A, Koutsojannis CM, Kounis NG, Alexopoulos D. Cefuroximeinduced coronary artery spasm manifesting as Kounis syndrome. Acta Cardiol 2005; 60: 341-5.

9. Cevik C, Nugent K, Shome GP, Kounis NG. Treatment of Kounis syndrome. Int J Cardiol 2010; 143: 223-6. 